\title{
Biological Control of Weeds by Fungi: Challenges and Opportunities
}

\author{
Hamid Cheraghian Radi ${ }^{*}$ and Ali Mohammad Banaei-Moghaddam² \\ ${ }^{1}$ Department of Microbial Biotechnology, School of Biology and Center of \\ Excellence in Phylogeny of Living Organisms, College of Science, University of \\ Tehran, Tehran, Iran \\ ${ }^{2}$ Laboratory of Genomics and Epigenomics (LGE), Department of Biochemistry, \\ Institute of Biochemistry and Biophysics (IBB), University of Tehran, Tehran, \\ Iran \\ *Corresponding Author: Hamid Cheraghian Radi, Department of Microbial \\ Biotechnology, School of Biology and Center of Excellence in Phylogeny of Living \\ Organisms, College of Science, University of Tehran, Tehran, Iran.
}

\author{
Received: March 17, 2020 \\ Published: April 17, 2020 \\ (C) All rights are reserved by Hamid \\ Cheraghian Radi., et al.
}

ORCID ID: https://orcid.org/0000-0002-2382-0197

\begin{abstract}
Weed plants are one of the main constraints to agriculture and cause considerable crop yield loss besides reducing product quality and leading to health and environmental threats. In comparison to various weed management strategies, biological controlespecially mycoherbicides-offer an innovative approach to address this problem. Today, the bio-control of weeds by mycoherbicide (either fungal spore suspension or their metabolites) has received significant academic attention and over the past few decades some of the high profile candidates became commercially available. Employing mycoherbicide proposes benefits including being environmentally friendly, cost effective, and identifying new herbicidal mechanisms. This review focuses on challenges that mycoherbicides encounter before their adoption. Besides, important factors in both selecting and improving a fungal strain as a mycoherbicide are reviewed. Additionally, using integrated weed management as complementary methods to elevate the efficacy of mycoherbicides have been considered.
\end{abstract}

Keywords: Weed Management; Agriculture; Biological Control; Mycoherbicides

\section{Introduction}

Weeds are regarded as unwanted and undesirable plants, associated with declines in crop yields and quality, causing health and environmental hazards and account for more than $30 \%$ of total losses caused by all the pests [1]. Weeds can reduce crop yields by an average of $12 \%$, which translates to $\$ 32$ billion in losses per year [2].

Common methods of weed control that are, mechanical and chemical approaches, associate with some drawbacks including being: costly, energy intensive, troublesome, having undesirable effects to the environment, development of resistance and the potential for injury to non-target organisms. Hence, there is a necessity to search for and develop new, economically and environmentally sustainable weed control technology. Using plant pathogens as biological control agents is one of the well-known alternatives to manage weed plants in disturbed environments [3]. Generally, two basic methods are applied for biological control of weeds: the classical and the bio-herbicide approaches. In classical strategy a natural predator or pathogen of a weed species is simply released into weed populations and the expectation is that it will be capable to persist, increase and disperse naturally throughout the entire weed population and provide ongoing reduction of the weed species population throughout an entire ecosystem [4]. On the other hand, the bio-herbicide approach (also referred to as the inundative strategy) utilizes indigenous plant pathogens such as fungal or bacterial suspensions that are isolated from weeds and are cultured to produce large numbers of infective propagules. These are applied at rates that will destroy the weed species within a managed area. Annual applications of bio-herbicides are vital since the plant pathogen does not generally survive in adequate numbers between growing seasons [2].

Typically, in different studies, a wide range of organisms including nematodes, insects, bacteria, and fungi are used as bio-control agents. Biological control of weeds with phytopathogenic fungi of- 
fers prospects for overcoming several of the aforementioned inadequacies [5]. Scientific activity in mycoherbicide studies has increased significantly and application of registered or unregistered mycoherbicides has also expanded worldwide [6].

This review will focus on the use of mycoherbicide agents to control weeds and it will discuss incentives to develop this technology, factors that affect their efficacy in the natural environment, effects of mycoherbicides on weed plant physiology, and methods for improving fungi virulence toward weed plants.

\section{Successful mycoherbicides}

From 1960s until now, hundreds of different fungal strains throughout the world were assessed according to their competency to prevent invasive weed plants in both greenhouse and field conditions. The results of these studies have introduced several mycoherbicides for controlling some of the noxious weed species. Table 1 includes some of fungi with the high potential of phyto-pathogenicity. Besides, there are quite a few mycoherbicide candidates that have shown promise in greenhouse and/or field trials (Table

\begin{tabular}{|c|c|c|c|c|c|}
\hline Bioherbicide agent & Target weed & $\begin{array}{l}\text { Intended } \\
\text { system }\end{array}$ & Stage of development & Country & Reference \\
\hline $\begin{array}{l}\text { Colletotrichum } \\
\text { gloeosporioides f.sp. ae- } \\
\text { schynomene }\end{array}$ & $\begin{array}{c}\text { Aeschynomene virginica (Northern } \\
\text { jointvetch) }\end{array}$ & Croplands & $\begin{array}{c}\text { Registered as Collego, no longer } \\
\text { available }\end{array}$ & USA & {$[12]$} \\
\hline $\begin{array}{l}\text { Colletotrichum gloeospori- } \\
\text { oides f.sp. malvae }\end{array}$ & Malva pusilla (Round leafmallow) & Croplands & Registered as BioMal & Canada & [13] \\
\hline Phoma chenopodicola & $\begin{array}{c}\text { Chenopodium album } \\
\text { (Lamb'squarters), Cirsium arvense } \\
\text { (Creepingthistle), Setaria viridis } \\
\text { (Greenfoxtail), Mercurialis annua } \\
\text { (Annual mercury) }\end{array}$ & Croplands & Research phase & Italy & {$[14]$} \\
\hline Phoma macrostoma & Dicot plants & Turf & $\begin{array}{l}\text { 94-44B strain registered with } \\
\text { EPA and PMRA in } 2011\end{array}$ & Canada & [15] \\
\hline Sclerotinia minor & \begin{tabular}{|c|} 
Taraxacum officinale (Dandelion), \\
Trifolium repens (White clover), and \\
Plantago minor (Broad leaf plantain)
\end{tabular} & Turf & $\begin{array}{l}\text { Registered as Sarritor, no lon- } \\
\quad \text { ger available }\end{array}$ & Canada & [16] \\
\hline $\begin{array}{l}\text { Chondrostereum purpu- } \\
\text { reum strain HQ1 }\end{array}$ & $\begin{array}{l}\text { Re-growth of deciduous trees and } \\
\text { shrubs }\end{array}$ & Woodlands & $\begin{array}{l}\text { Registered as Mycotech Paste } \\
\text { with PMRA in 2002, and with } \\
\text { EPA in 2005 }\end{array}$ & $\begin{array}{l}\text { North } \\
\text { America }\end{array}$ & [8] \\
\hline $\begin{array}{l}\text { Chondrostereum purpu- } \\
\text { reum }\end{array}$ & $\begin{array}{l}\text { Prunus serotina (American bird } \\
\text { cherry) and Populus euramericana } \\
\text { (poplar) }\end{array}$ & Woodlands & $\begin{array}{l}\text { Registered as BioChon, no } \\
\text { longer available }\end{array}$ & $\begin{array}{l}\text { USA, Canada. } \\
\text { New Zealand }\end{array}$ & [17] \\
\hline $\begin{array}{l}\text { Chondrostereum purpu- } \\
\text { reum strain PFC } 2139\end{array}$ & $\begin{array}{l}\text { Re-growth of deciduous trees and } \\
\text { shrubs }\end{array}$ & Woodlands & $\begin{array}{l}\text { Registered as Chontrol Paste } \\
\text { with EPA in 2004, and with } \\
\text { PMRA in } 2007\end{array}$ & $\begin{array}{l}\text { North } \\
\text { America }\end{array}$ & [8] \\
\hline Puccinia canaliculata & Cyperus esculentus & Croplands & Registered as Dr. BioSedge & USA & [18] \\
\hline Alternaria destruens & Cuscata spp. (Dodder species) & Croplands & $\begin{array}{c}\text { Registered as Smolder G and } \\
\text { Smolder WP with EPA in 2005, } \\
\text { no longer commercially avail- } \\
\text { able }\end{array}$ & USA & [19] \\
\hline Alternaria sonchi & $\begin{array}{c}\text { Sonchus arvensis (Perennial sowthis- } \\
\text { tle) }\end{array}$ & Croplands & Research phase & $\begin{array}{l}\text { America, } \\
\text { Europe }\end{array}$ & {$[20]$} \\
\hline Phytophthora palmivora & Morrenia odorata (Strangler vine) & $\begin{array}{l}\text { Citrus or- } \\
\text { chards }\end{array}$ & $\begin{array}{l}\text { Registered as DeVine (No lon- } \\
\text { ger commercially available) }\end{array}$ & USA & {$[21]$} \\
\hline Fusarium solani & $\begin{array}{c}\text { Orobanche aegyptiaca (Egyptian } \\
\text { broomrape) }\end{array}$ & Croplands & Research phase & India, Israel & {$[22]$} \\
\hline Nimbya alternantherae & $\begin{array}{l}\text { Alternanthera philoxeroides (Al- } \\
\text { ligatorweed) }\end{array}$ & $\begin{array}{l}\text { Aquatic, up- } \\
\text { land sites }\end{array}$ & Research phase & Worldwide & [23] \\
\hline Myrothecium verrucaria & $\begin{array}{l}\text { Brunnichia ovate (Redvine), Campis } \\
\text { radicans (Trumpetcreeper), Puer- } \\
\text { aria lobata (Kudzu) }\end{array}$ & $\begin{array}{l}\text { Croplands, } \\
\text { wastelands, } \\
\text { natural } \\
\text { areas }\end{array}$ & Research phase & $\begin{array}{l}\text { Southern } \\
\text { U.S. }\end{array}$ & {$[24]$} \\
\hline
\end{tabular}

Table 1: A list of either successful or potential candidates of mycoherbicides. 
1). Some specific genera of fungi, such as Colletotrichum, Phoma, Sclerotinia, Alternaria, Fusarium and Puccinia received the majority of attention as bioherbicide candidates [7].

The mycoherbicide product Myco-Tech ${ }^{\mathrm{TM}}$ (Chondrostereum purpureum) was registered in 2002. This pathogen is an important fungal species which causes severe disease in many tree species in North America and is liable for the birch dieback in North American forests to a great extent [8].

The mycoherbicide DeVine is a formulation of the fungus Phytophthora palmivora that was twice registered in 1981 and 2006. The fungus was isolated from Morrenia odorata (strangler vine) in Florida and was applied to control the same plant. Though the product was re-registered in 2006, due to the limited market, it is not commercially available now [9].

One of the most promising aspects of using mycoherbicides is that they are cost beneficial. According to Page and Lacey (2006), the aggregate results of benefit/cost ratio (B/C ratio) for many mycoherbicide indicate an overall $\mathrm{B} / \mathrm{C}$ ratio of 23:1 [10]. In another project for controlling Chondrilla juncea, the evaluation of $\mathrm{B} / \mathrm{C}$ ratio of utilized fungal pathogens to control this weed, it was found that the accrued benefits to the users have been significant such as a 100:1 to $200: 1$ [11].

\section{Phytotoxins}

Fungi are well known for their ability to produce various phytotoxic metabolites with herbicidal characteristics. They including, but not limited to, various classes of natural compounds such as amino acids, aromatic, ethanones, nonenolides, furopyrans, trichothecenes, spirophytotoxins, coumarins and isocoumarins [25]. Table 2 shows a list of mycoherbicide phytotoxins that strongly target a number of weed plants.

\begin{tabular}{|l|c|c|c|c|}
\hline \multicolumn{1}{|c|}{ Pathogen } & Weed target & Phytotoxin & Mode of action & Reference \\
\hline Cantharellus cibarius & Eichhornia crassipes & 5-Methyl-Trp & Trp synthase & CF1 ATPase \\
\hline Alternaria tenuis & Galium aparine & Tentoxin & [30] & [31] \\
\hline Preussia fleischhakii & Arabidopsis thaliana & Cyperin & Protoporphyrinogen oxidase and Lipid synthesis & {$[32]$} \\
\hline Alternaria alternata & Lemna pausicostata & AAL-toxins & Ceramide synthase & {$[33]$} \\
\hline Fusarium spp. & Lemna pausicostata & Fumonisins & Membrane functions and lipid stability & {$[33]$} \\
\hline Nectria sp. DA060097 & Amaranthus retroflexus & Cinnacidin & Unknown & {$[34]$} \\
\hline Gibberella fujikuroi & Arabidopsis thaliana & GA mimic & GA3 & {$[35]$} \\
\hline
\end{tabular}

Table 2: A list of molecular target sites of fungal phytotoxins.

During last decades, weed researchers have dedicated considerable time and expenditures in chemically characterizing many phytotoxins, yet in comparison to the opportunities, trivial efforts have been made to evaluate their weed control capacity [26].

Studies on Chenopodolin, a phytotoxic metaboilte from Phoma chenopodicola, have shown that it has the capability to cause extensive necrotic lesions on lamb's quarter (Chenopodium album), creeping thistle (Cirsium arvense), green foxtail (Setaria viridis) and annual mercury (Mercurialis annua) [14].

Tentoxin is another fungal phytotoxin which was extracted from several Alternaria species. Duke., et al. reported that when tentoxin was applied against johnsongrass (in corn farm) and both broadleaf and narrowleaf weeds (in soybeans farm), the phytotoxic metabolite provide a considerable weed control activity by causing severe chlorosis [27]. Furthermore, two phytotoxins, ascaulitoxin and trans-4-aminoproline, from fungal species Ascochyta caulina were isolated and proposed as bioherbicide agents against Chenopodium album. As a companion agent, the toxin solutions along with the fungal spore suspension showed promising results in controlling the troublesome weed plant [28].

Another phytotoxic metabolite, named ascosonchine, was isolated from culture filtrate of fungal pathogen Ascochyta sonchi. The toxin was proposed as a potent biocontrol agent against Sonchus arvensis, that is one of the most important perennial weeds of agrarian crops [29].

Improving the mycoherbicide agent

As we discussed earlier, for assessing the potential of a mycoherbicide, weed researchers must consider some important characteristics such as host specificity, ability to grow and sporulate on culture media, genetic stability and virulence. A large number of studies have shown that lack of these properties will lead to low success rates of mycoherbicide products in terms of commercialization [36]. As it has been declared before, microorganisms can naturally modify their phenotypic characteristics by manipulating their genetic pool [37]. Various genomic approaches have been evolved to track the molecular bases of these modifications. Stuke- 
nbrock., et al. (2008) mentioned scenarios such as horizontal gene transfer and hybridization as the possible processes which could lead to the emergence of either new host range or virulence in microorganisms and these scenarios, eventually, could result in birth of new plant pathogens [38]. As a matter of fact, molecular biologists used the clues, such as naturally occurring horizontal gene transfer and developed many methods to perform these processes in the laboratory to evolve fungi with high aggressiveness and host specificity toward intended weed plants. There are many techniques which have been prosperously applied to introduce foreign DNA into fungal species including electroporation, utilizing calcium chloride and polyethylene glycol, restriction enzyme mediated integration, lithium acetate and transformation by Agrobacterium [39]. There are limited examples of fungal transformation to elevate the potency of mycoherbicide. Dickman., et al. (1989) showed that transferring of cutinase producing gene from Fusarium solani to a species of Mycosphaerella could transform this fungus to a phytopathogen that could cause severe lesions on papaya plant [40]. In fact, after this study, there have been several articles of transforming different fungi to create strong mycoherbicides [41].

Cohen., et al. (2002) stated that up-regulation of indole acetic acid production in Fusarium oxysporum by transforming with iaa $\mathrm{H}$ and iaa $\mathrm{M}$ genes could double the efficacy of the mycoherbicide [42]. In another study, Amsellem., et al. (2002) declared that by transforming Colletotrichum coccoides with necrosis and ethylene inducing gene (NEP1) from F. oxysporum, a 9-fold increase in pathogenicity and a reduction of dew period requirement against Abutilon theophrasti attained [43].

\section{Effect of fungal bioherbicides on weed physiology}

Though a few researches have been run to clarify the physiological aspects of weed-fungi interaction during mycoherbicide treatments, some studies have underlined important metabolic processes, such as ones related to photosynthesis, hormones, antioxidants and nutrient uptake [44].

Fungal species inhibit weed plant growth by different mechanisms. For example, pathogenic fungi Phoma macrostoma attacks, colonizes and passes into the root part of the weed plant and develop its mycelium in the vascular trachea to obstruct the food uptake. Curvularia intermedia by producing the phytotoxin $\alpha, \beta$ dehydrocurvularin hinders mitosis in cells of root tip and inhibits seedling development [45]. Besides, pectinase producing fungi can penetrate the cell wall of the weed plant by tearing apart the polysaccharide layers, enlarging the pores and releasing many lethal molecules into infected weed plant cells [46]. Moreover, the extracellular lipases of fungal species use the stored lipids in the endosperm of plant seeds for growth [47].
Indole-3-acetic acid (IAA) is a natural hormone that many bacteria and fungi can produce. Enterobacter sp. I-3 is a gram-negative bacterium that produces and secretes high concentrations of IAA to weed plants. By doing so, the endogenous IAA of the plant will enhance which result in the synthesis of aminocyclopropane1-carboxylate (ACC), a motivator of ethylene biosynthesis. In the end, ethylene causes a reduction in weed growth [48]. Although, fungi have the potential to be evaluate in this regard, studies related to assessing the role of fungal species IAA in weed control is in its infancy.

Photosynthesis is another important process of plants that could be considered as a potential target for mycoherbicides. Macrocidin is a fungal metabolite which produced by genus Phoma. This phytotoxin interfere with carotenoid production and results in increased phytone production. Consequently, the ratio of $\beta$-carotene to lutein will decline; this will leads to decreases in both chlorophyll synthesis and photosynthetic gas exchange [49].

Other phytotoxic compounds, including tenuazonic acid, isotenuazonic acid, N2- $\beta$-D-glucopyranoside, trans-4-amino-D-proline, cercosporin, beticolin, Nep1, trichothecene, $\beta-1,4$-exoglucanase, glucosidase, xylanase, $\beta-1,4$-endoglucanase and organic acids are produced by pathogenic fungi to control germination and development of weeds [50]. Table 3 provides a list of pathogenic fungi along with their mechanisms of action on weed plants.

\section{Integrated weed management}

In many instances, mycoherbicides will not provide the satisfying results to obviate the problem of invasive weed plants. In these cases, scientists in the field of weed science have shown that integrated weed management, which includes, physical, cultural, chemical and biological methods, could be a promising option. In fact, numerous studies have shown the great potential of mycoherbicides in conjunction with other anti-weed agents. For example, in the field trail, Wandeler., et al. (2008) provided a systematic rust infection in creeping thistles (Cirsium arvense) by using weevils as an insect vector to apply Puccinia punctiformis against this weed [57]. In another research, instead of utilizing a single pathogen, a mixture of fungal species, Phomopsis amaranthicola, Alternaria cassia, Colletotrichum dematium f.sp. crotalariae, Fusarium udum f.sp. crotalariae were used to control three weed plant species (pigweed (Amaranthus hybridus L.), sicklepod (Senna obtusifolia) and showy crotalaria (Crotalaria spectabilis Roth.)) and in the end, the results of greenhouse study showed that after weeds inoculation with the mixture of fungi's spore suspension, all of the seedlings were killed in 7 days [58]. Furthermore, Caesar (2003) demonstrated a strong synergy between Fusarium oxysporum and Rhizoctonia solani either with larvae or adults of flea beetle for controlling Euphorbia 


\begin{tabular}{|c|c|c|c|}
\hline Pathogen & Bioherbicide stimulant & Mode of action on weed plants & Reference \\
\hline Alternaria alternate & Spore and culture & Leaf blight disease and inhibit seed germination & {$[50]$} \\
\hline Colletorichum coccodes & Spore & Induce disease and POD activity & {$[51]$} \\
\hline $\begin{array}{l}\text { Colletotrichum } \\
\text { gloeosporioides }\end{array}$ & Spore & $\begin{array}{c}\text { High rate of mortality, dry weight reduction and reduce } \\
\text { plant growth, anthracnose lesions in stems, } \\
\text { polysaccharides changes in cell wall }\end{array}$ & [46] \\
\hline $\begin{array}{l}\text { Curvularia eragrostidis } \\
\text { isolate QZ-2000 }\end{array}$ & $\begin{array}{l}\text { Spore and culture (a, } \beta- \\
\text { dehydrocurvularin) }\end{array}$ & $\begin{array}{l}\text { Inhibit seed germination, biomass, chlorophyll, } \\
\text { photophosphorylation, Mg2+ ATPase, mitosis of root } \\
\text { tips, increase necrosis, mortality }\end{array}$ & [45] \\
\hline $\begin{array}{l}\text { Epicoccum } \\
\text { purpurascens }\end{array}$ & Spore & Inhibit seed germination and disease induction & {$[52]$} \\
\hline Fusarium equiseti & Spore & Inhibit seed germination and disease induction & [52] \\
\hline Fusarium oxysporum & Spore (24-kDa protein (Nep1)) & $\begin{array}{l}\text { Disease induction, necrosis, ethylene production, inhibit } \\
\text { seed germination and infect seed testa and endosperm }\end{array}$ & [53] \\
\hline Myrothecium roridum & $\begin{array}{c}\text { Spore and culture }(\beta-1,4 \text {-exoglucanase, } \\
\beta-1,4 \text {-endoglucanase, glucosidase, xyla- } \\
\text { nase and pectinase) }\end{array}$ & Inhibit seed germination, growth and disease & {$[54]$} \\
\hline $\begin{array}{l}\text { Myrothecium verru- } \\
\text { caria }\end{array}$ & Spore & Inhibit weed growth, chlorophyll and induce disease & [55] \\
\hline Phoma macrostoma & Spore & Inhibit weed growth and disturb root cells & {$[15]$} \\
\hline Phoma macrostoma & Spore and culture (macrocidins) & $\begin{array}{l}\text { Inhibit growth, chlorosis, photosynthesis, carotenoid } \\
\text { Biosynthesis }\end{array}$ & [49] \\
\hline Pythium spp. & Culture & $\begin{array}{l}\text { Reduce weed emergence and increase weed seedling } \\
\text { Mortality }\end{array}$ & {$[56]$} \\
\hline
\end{tabular}

Table 3: Mechanism of action of fungal bioherbicides on weed physiology.

esula/virgate. Moreover, mycoherbicides could exacerbate the efficacy of chemical herbicides [59]. Vurro., et al. (2001) proved that combination of herbicides with phytotoxins of Ascochyta caulina provide a better control of Chenopodium album [28]. Gressel (2010) points out that glyphosate is more frequently used along with plant pathogens in integrated weed control. He believes that the probable scenario behind this fact is that glyphosate is very capable to hamper various weed defense mechanisms [60]. Boyette., et al. (2008) showed that glyphosate and the fungus Myrothecium verrucaria had a synergistic relationship in controlling redvine (Brunnichia ovata) and trumpet creeper (Campis radicans) in a field study [24]. The mechanisms by which mycoherbicides synergize glyphosate are not quite clear yet.

\section{Challenges for weed control by mycoherbicides}

There are several challenges in developing a prosperous mycoherbicide (Figure 1). In fact, these challenges divide into economic, environmental or political categories.

One of the central challenges in using mycoherbicide agents to control weed plants is to finding suitable strategies of application that allow the unvarying distribution of the agent at the desired site. The uniform and accurate application of microbial suspension close to the target weed would decrease the cost of treatment and the risks of non-target effects [61].

One of the most important problems related to the release of a mycoherbicide in the environment for weed bio-control is the lack of knowledge about the actual host range of the microorganism in the environment. Several studies have shown that some agents introduced for alien weed control have invaded non target plants [62] and this issue has resulted in raising concerns both among weed scientists and governments. For example, Phytophthora palmivora, the fungus formulated as Devine, was intended to target Morrenia odorata, but it also infects some non-target crops such as onion, cantaloupe, watermelon, okra, tomato, endive, cucumber, English pea, and carrot [63]. Thus, the host range and environmental impacts of mycoherbicides must be assessed thoroughly.

Another important factor in determining the potential of fungal strain as a mycoherbicide is that the phyto-pathogen must be easily culturable in artificial media; the pathogen must be able to propa- 


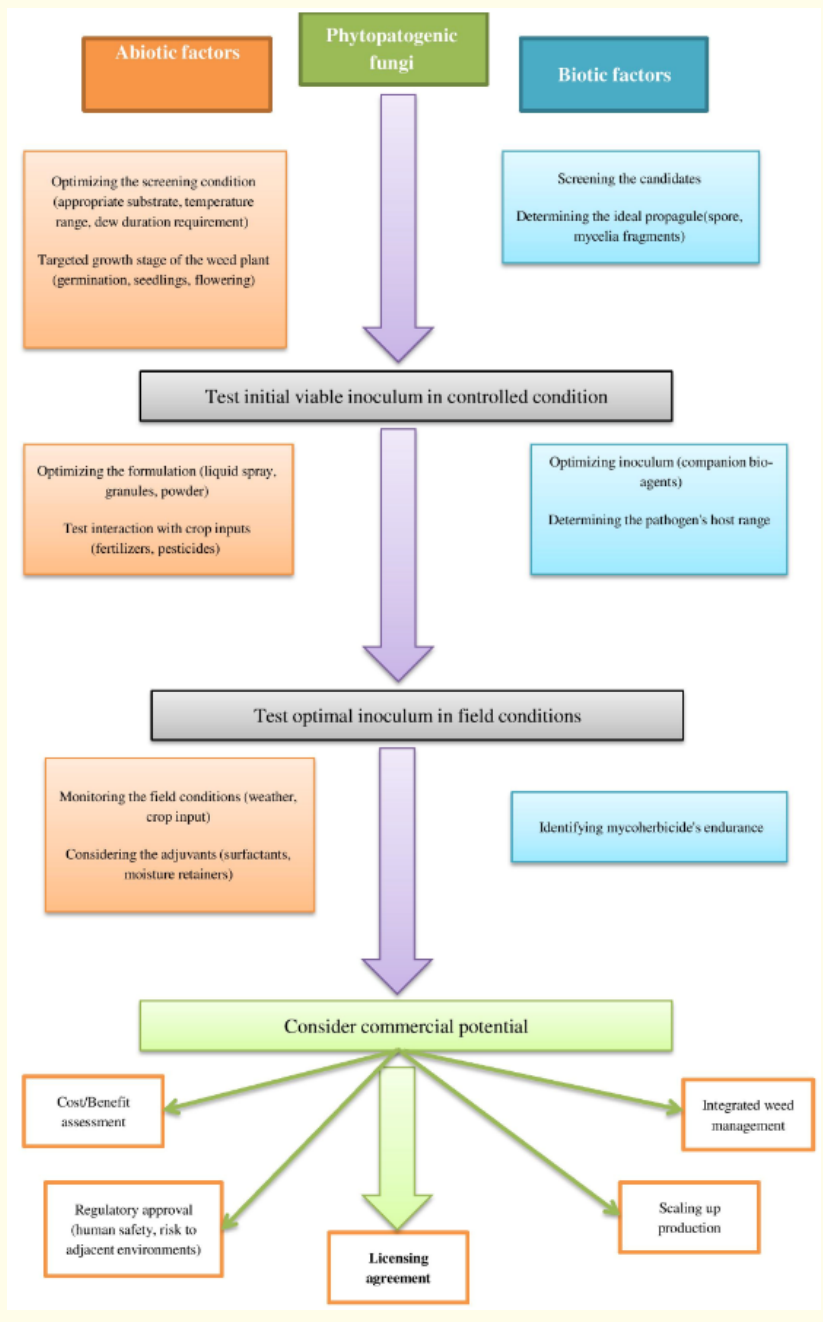

Figure

gate using conventional approaches e.g. liquid fermentation and it ought to be genetically steadfast and specific to the intended weed plant [64].

The interaction of temperature and moisture also has a critical impact on the success or failure of myco-herbicide agent [65]. Due to the fact that relative humidity of cold air is higher than warm air, because of the lower rate of evaporation, thus the duration of leaf wetness will increase and consequently the efficacy of the mycoherbicide will invigorate [65]. According to the findings of a study that was carried out to assess the potential of mycoherbicide product Sarritor, it was shown that compared to warmer temperatures, the efficacy of the weed control agent was very high in temperatures below $20^{\circ} \mathrm{C}[66]$.

The fungal pathogen, Phloeospora heraclei showed a high potential to control giant hogweed (Heracleum mantegazzianum) in vitro based screening trials but the mycoherbicide's further evalu- ation was ceased when it was discovered that it has a great tendency toward several related crop plant species [67].

The tendency toward utilization of mycoherbicides is dissimilar in different parts of the world. Investment on this technology in some countries, such as Canada and USA, is heavy [68], while in others such as New Zealand and European countries low number of projects has been funded on this topic [69].

Bio-herbicide approach has been known to be more economical in comparison with current technologies; However some specific reasons including: the long time frames for development and some disappointing examples of weed bio-control, have reduced the rate of their adoption [70].

Also, despite the promising examples of fungi that have shown high potential of weed control, scientific and legislative hesitancies, along with undesirable public perception or cognition about pathogenic microorganisms (pathophobia), negatively influenced some countries, especially European countries in using these agents for weed control [69].

As a matter of fact, developing a prosperous mycoherbicide agent face quite a few challenges, and continued research and development are required to verify their capability as the alternative for weed management.

\section{Conclusion}

Biological control of weeds with mycoherbicides has been satisfactorily implemented for several important weed plants. Further researches are required to elevate our understanding of different aspects of weed-fungus interaction. By doing so, we will be able to apply new strategies to fight these noxious weeds. The most important factors related to having a perfect mycoherbicide product are: specificity, competitiveness, cost efficiency, and being environmentally sound. Producing new formulations and finding an efficient delivery system are vital to extend the shelf-life and efficiency of the mycoherbicide agent in different environmental conditions. Moreover, herbicidal activity of the mycoherbicide agents could be enhanced with research on strain selection criterions including genetically engineered fungal pathogen to create a mycoherbicide that is both more specific and more virulent. Weed control should not be considered a self-contained option but may be best if integrated with other approaches. In fact, Chemical herbicides and other biological agents such as insects could play a complementary role beside the mycoherbicide agent and, surely, they can invigorate the phyto-pathogenic potential of the final product.

\section{Bibliography}

1. Gadermaier G., et al. "Allergens of weed pollen: an overview on recombinant and natural molecules". Methods 66.1 (2014): 55-66. 
2. Yandoc-Ables C., et al. "Plant pathogens at work: Progress and possibilities for weed biocontrol classical versus bioherbicidal approach". Plant Health Progress 8.1 (2007): 32.

3. Ash GJ. "Biological Control of Weeds with Mycoherbicides in the Age of Genomics". Pest Technology 5.1 (2011): 41-47.

4. Shaw RH., et al. "The life history and host range of the Japanese knotweed psyllid, Aphalara itadori Shinji: potentially the first classical biological weed control agent for the European Union". Biological Control 49.2 (2009): 105-113.

5. Hoagland RE., et al. "Bioherbicides: research and risks". Toxin Reviews 26.4 (2007): 313-342.

6. Goodwin PH. "A molecular weed-mycoherbicide interaction: Colletotrichum gloeosporioides f. sp. malvae and round-leaved mallow, Malva pusilla". Canadian Journal of Plant Pathology 23.1 (2001): 28-35.

7. Barton J. "Bioherbicides: All in a Days Work for a Superhero". What's New in Biological Control of Weeds 34 (2005): 4-6.

8. Setliff E. "The wound pathogen Chondrostereum purpureum, its history and incidence on trees in North America". Australian Journal of Botany 50.5 (2002): 645-651.

9. Bailey KL. "The bioherbicide approach to weed control using plant pathogens". Integrated Pest Management: Elsevier (2014): 245-266.

10. Page ALacey K. "Economic impact assessment of Australian weed biological control". CRC for Australian Weed Management (2006).

11. Cullen J. "Bringing the cost benefit analysis of biological control of Chondrilla juncea up to date". Proceedings of the VI International Symposium on Biological Control of Weeds (1984): 145-152.

12. Daniel J., et al. "Biological Control of Northern Jointvetch in Rice by An Endemic Fungal Disease". Weed Science 21.4 (1973): 303-307.

13. Mortensen K. "The potential of an endemic fungus, Colletotrichum gloeosporioides, for biological control of round-leaved mallow (Malva pusilla) and velvetleaf (Abutilon theophrasti)". Weed Science 36.4 (1988): 473-478.

14. Cimmino A., et al. "Chenopodolin: a phytotoxic unrearranged ent-pimaradiene diterpene produced by Phoma chenopodicola, a fungal pathogen for Chenopodium album biocontrol". Journal of Natural Products 76.7 (2013): 1291-1297.
15. Bailey KL., et al. "The effects of Phoma macrostoma on nontarget plant and target weed species". Biological Control 58.3 (2011): 379-386.

16. Riddle GE., et al. "Virulence of Sclerotinia sclerotiorum and $S$. minor on dandelion (Taraxacum officinale)". Weed Science 39.1 (1991): 109-118.

17. De Jong MD. "The BioChon story: deployment of Chondrostereum purpureum to suppress stump sprouting in hardwoods". Mycologist 14.2 (2000): 58-62.

18. Phatak SC., et al. "Biological control and its integration in weed management systems for purple and yellow nutsedge (Cyperus rotundus and C. esculentus)". Weed Technology 1.1 (1987): 84-91.

19. Simmons EG. "Alternaria themes and variations (224-225)". Mycotaxon 68 (1998): 417-427.

20. Evidente A., et al. "Alternethanoxins A and B, polycyclic ethanones produced by Alternaria sonchi, potential mycoherbicides for Sonchus arvensis biocontrol". Journal of Agricultural and Food Chemistry 57.15 (2009a): 6656-6660.

21. Burnett H., et al. "Biological control of milkweed vine with a race of Phytophthora citrophthora". Proceedings of the annual meeting (1974).

22. Sharma P., et al. "First Report of Fusarium Wilt in the Broomrape Parasite Growing on Brassica spp. in India". Plant Disease 95.1 (2011): 75-75.

23. Pomella AWV., et al. "Nimbya alternantherae a potential biocontrol agent for alligator weed, Alternanthera philoxeroides". Bio Control 52.2 (2007): 271-288.

24. Boyette CD., et al. "Redvine (Brunnichia ovata) and trumpetcreeper (Campsis radicans) controlled under field conditions by a synergistic interaction of the bioherbicide, Myrothecium verrucaria, with glyphosate". Weed Biology and Management 8.1 (2008): 39-45.

25. Cimmino A., et al. "Fungal phytotoxins with potential herbicidal activity: chemical and biological characterization". Natural Product Reports 32.12 (2015): 1629-1653.

26. Duke S., et al. "Phytotoxins of microbial origin with potential for use as herbicides". Critical Reports on Applied Chemistry 35 (1996): 82-112. 
27. Duke Solydon J. "Herbicides from natural compounds". Weed Technology 1.2 (1987): 122-128.

28. Vurro M., et al. "Enhancement of efficacy of Ascochyta caulina to control Chenopodium album by use of phytotoxins and reduced rates of herbicides". Biological Control 21.2 (2001): 182-190.

29. Evidente A., et al. "Ascosonchine, the enol tautomer of 4-pyridylpyruvic acid with herbicidal activity produced by Ascochyta sonchi". Phytochemistry 65.4 (2004): 475-480.

30. Hsiao P., et al. "Plant native tryptophan synthase beta 1 gene is a non-antibiotic selection marker for plant transformation". Planta 225.4 (2007): 897-906.

31. Meiss E., et al. "Molecular processes of inhibition and stimulation of ATP synthase caused by the phytotoxin tentoxin". Journal of Biological Chemistry 283.36 (2008): 24594-24599.

32. Dayan FE., et al. "A pathogenic fungi diphenyl ether phytotoxin targets plant enoyl (acyl carrier protein) reductase". Plant Physiology 147.3 (2008): 1062-1071.

33. Abbas HK., et al. "Fumonisin-and AAL-toxin-induced disruption of sphingolipid metabolism with accumulation of free sphingoid bases". Plant Physiology 106.3 (1994): 1085-1093.

34. Irvine NM., et al. "Synthesis and characterization of synthetic analogs of cinnacidin, a novel phytotoxin from Nectria sp". Pest Management Science: formerly Pesticide Science 64.9 (2008): 891-899.

35. Hedden P., et al. "Gibberellin biosynthesis in plants and fungi: a case of convergent evolution?" Journal of Plant Growth Regulation 20.4 (2001): 319-331.

36. Sands DCPilgeram AL. "Methods for selecting hypervirulent biocontrol agents of weeds: why and how". Pest Management Science: formerly Pesticide Science 65.5 (2009): 581-587.

37. Custers R., et al. "Genetic alterations that do or do not occur naturally; consequences for genome edited organisms in the context of regulatory oversight". Frontiers in Bioengineering and Biotechnology 6 (2018): 213.

38. Stukenbrock EHMc Donald BA. "The origins of plant pathogens in agro-ecosystems". Annual Review of Phytopathology 46 (2008): 75-100.
39. Zeilinger S. "Gene disruption in Trichoderma atroviride via Agrobacterium-mediated transformation". Current Genetics 45.1 (2004): 54-60.

40. Dickman M., et al. "Insertion of cutinase gene into a wound pathogen enables it to infect intact host". Nature 342.6248 (1989): 446.

41. Wang CSt Leger RJ. "A scorpion neurotoxin increases the potency of a fungal insecticide". Nature Biotechnology 25.12 (2007): 1455.

42. Meir S., et al. "Transforming a NEP1 toxin gene into two $\mathrm{Fu}$ sarium spp. to enhance mycoherbicide activity on Orobanchefailure and success". Pest Management Science: formerly Pesticide Science 65.5 (2009): 588-595.

43. Amsellem Z., et al. "Engineering hypervirulence in a mycoherbicidal fungus for efficient weed control". Nature Biotechnology 20.10 (2002): 1035

44. Radhakrishnan R., et al. "Bioherbicide Current knowledge on weed control mechanism". Ecotoxicology and Environmental Safety 158 (2018): 131-138.

45. Jiang SJ., et al. "Isolation and phytotoxicity of a metabolite from Curvularia eragrostidis and characterisation of its modes of action". Annals of Applied Biology 152.1 (2008): 103-111.

46. Boyette CD., et al. "Induction of infection in Sesbania exaltata by Colletotrichum gloeosporioides $f$. sp. aeschynomene formulated in an invert emulsion". World Journal of Microbiology and Biotechnology 26.5 (2010): 951-956.

47. Thomas H., et al. "Fusarium oxysporumf. sp. orthoceras, a Potential Mycoherbicide, Parasitizes Seeds of Orobanche cumana (Sunflower Broomrape): a Cytological Study". Annals of Botany 83.4 (1999): 453-458.

48. Park J-M., et al. "IAA producing Enterobacter sp. I-3 as a potent bio-herbicide candidate for weed control: a special reference with lettuce growth inhibition". Indian Journal of Microbiology 55.2 (2015): 207-212.

49. Hubbard M., et al. "Impact of macrocidins, produced by Phoma macrostoma, on carotenoid profiles of plants". Biological Control 89 (2015): 11-22.

50. Motlagh MRS. "Evaluation of Alternaria alternata causing leaf spot of barnyardgrass grown in rice fields". African Journal of Microbiology Research 6.21 (2012): 4481-4488. 
51. Ahn B., et al. "Enhancement of Colletotrichum coccodes virulence by inhibitors of plant defense mechanisms". Biocontrol Science and Technology 15.3 (2005): 299-308.

52. Motlagh MRS. "Evaluation of Epicoccum purpurascens as biological control agent of Echinochloa spp. in rice fields". Journal of Food, Agriculture and Environment 9.1 (2011): 394-397.

53. Ray P Vijayachandran LS. "Evaluation of indigenous fungal pathogens from horse purslane (Trianthema portulacastrum) for their relative virulence and host range assessments to select a potential mycoherbicidal agent". Weed Science 61.4 (2013): 580-585.

54. Piyaboon 0., et al. "Pathogenicity, host range and activities of a secondary metabolite and enzyme from Myrothecium roridum on water hyacinth from Thailand". Weed Biology and Management 16.3 (2016): 132-144.

55. Hoagland R., et al. "Bioherbicidal effects of Myrothecium verrucaria on glyphosate-resistant and-susceptible Palmer amaranth biotypes" (2013).

56. Hoagland L., et al. "Role of native soil biology in Brassicaceous seed meal-induced weed suppression". Soil Biology and Biochemistry 40.7 (2008): 1689-1697.

57. Wandeler H., et al. "Establishing systemic rust infections in Cirsium arvense in the field". Biocontrol Science and Technology 18.2 (2008): 209-214.

58. Chandramohan S Charudattan R. "A multiple-pathogen system for bioherbicidal control of several weeds". Biocontrol Science and Technology 13.2 (2003): 199-205.

59. Caesar A. "Synergistic interaction of soilborne plant pathogens and root-attacking insects in classical biological control of an exotic rangeland weed". Biological Control 28.1 (2003): 144-153.

60. Gressel J. "Herbicides as synergists for mycoherbicides, and vice versa”. Weed Science 58.3 (2010): 324-328.

61. Boari A., et al. " Microbigation: delivery of biological control agents through drip irrigation systems". Irrigation Science 26.2 (2008): 101-107.

62. Suckling DM. "Benefits from biological control of weeds in New Zealand range from negligible to massive: a retrospective analysis". Biological Control 66.1 (2013): 27-32.
63. Ridings W., et al. "Biological control of milkweed vine in Florida citrus groves with a pathotype of Phytophthora citrophthora". Proceedings of the IV ${ }^{\text {th }}$ International Symposium on the Biological Control of Weeds (1976): 224-240.

64. Templeton GE., et al. "Biological weed control with mycoherbicides". Annual Review of Phytopathology 17.1 (1979): 301-310.

65. Casella F., et al. "Effectiveness and technological feasibility of bioherbicide candidates for biocontrol of green foxtail (Setaria viridis)". Biocontrol Science and Technology 20.10 (2010): 1027-1045.

66. Siva C. "Alternative strategies for broadleaf weed management in residential lawns" (2014).

67. Pyšek P., et al. "Ecology and management of giant hogweed (Heracleum mantegazzianum)". CAB International, Wallingford (2007): 352.

68. Cordeau S., et al. "Bioherbicides: dead in the water? A review of the existing products for integrated weed management". Crop Protection 87 (2016): 44-49.

69. Vurro MEvans H. "Opportunities and constraints for the biological control of weeds in Europe. Proceedings of the XII international symposium biological control weeds". CAB International, Wallingford (2008): 455-462.

70. Ani O., et al. "Overview of Biological Methods of Weed Control". Biological Approaches for Controlling Weeds (2018): 5.

\section{Assets from publication with us}

- Prompt Acknowledgement after receiving the article

- Thorough Double blinded peer review

- Rapid Publication

- Issue of Publication Certificate

- High visibility of your Published work

Website: https://www.actascientific.com/

Submit Article: https://www.actascientific.com/submission.php Email us: editor@actascientific.com

Contact us: +919182824667 